\title{
PENGARUH KOMPETENSI AGEN ASURANSI TERHADAP LOYALITAS NASABAH PADA PERUSAHAAN ASURANSI JIWA BERSAMA BUMIPUTERA 1912 KANTOR CABANG SYARIAH PALMERAH
}

\author{
Aria Fariska ${ }^{1}$ dan Fahmi Syahbudin ${ }^{2}$
}

1Santri Tahfidz di Pondok Darus-Sofa, Bogor, Jawabarat. Email: ekonomrobbani29@yahoo.com

2Program Studi Perbankan Syariah, Sekolah Tinggi Ekonomi Islam SEBI, Depok, Jawa Barat. Email: ayanafnaf@gmail.com

\begin{abstract}
ABSTRAK: Penelitian ini bertujuan untuk mengetahui pengaruh Kompetensi Agen Asuransi syariah, yaitu kompetensi pengetahuan, kompetensi skill, dan perilaku agen terhadap loyalitas nasabah asuransi AJB Bumiputera 1912 syariah cabang palmerah. Penelitian ini adalah penelitian kuantitatif. Data yang akan digunakan adalah data primer dengan kuesioner. metode yang digunakan adalah metode SEM (structural equation model). Hasil tes menunjukan bahwa pengetahuan secara parsial mempunyai pengaruh negative yang tidak signifikan. Sedangkan skill memiliki hubungan positif dan signifikan mempengaruhi loyalitas nasabah. Hal ini sejalan dengan perilaku agen yang juga signifikan mempengaruhi loyalitas. Secara bersamaan ketiga variable ini secara signifikan mempengaruhi loyalitas nasabah.
\end{abstract}

Kata kunci: Kompetensi Pengetahuan, kompetensi Skill, kompetensi Perilaku, loyalitas nasabah dan SEM.

ABSTRACT: This research aims to know the influence of the Insurance Agent's competence consists of knowledge of the agen and the Agent's skills towards the customer loyality on AJB Bumiputera 1912 Palmerah sharia branch office. Type of this research is quantitative research. Methods and techniques of data analysis in this study using Structural Equation. Based on the test, Partially substantiated knowledge competency that influence negative and not significant on customer loyalty, while competency with respect to the skills is significant and positive impact on customer loyalty, also competency of behaviour has positive relation but not significant to customer loyality. Simultaneously proved that these three independent variables (knowledge competencies, skills competence and behavior competence) have an influence positively and significantly to the dependent variables (customer loyalty.

Keywords: Knowledge Competence, Skill Competence, Behavior Competence, Customer Loyalty, SEM 


\section{PENDAHULUAN}

Manusia sebagai seorang konsumen membutuhkan sebuah fasilitas yang dapat memberikan rasa aman dan menjamin keberlangsungan hidupnya, keluarganya, maupun usahanya. Oleh sebab itu, asuransi merupakan sebuah jawaban dari kebutuhan tersebut. Perusahaan asuransi merupakan perusahaan yang bergerak dalam bidang jasa yang menawarkan jasa proteksi sebagai produknya kepada masyarakat yang membutuhkan dan selanjutnya diharapkan akan menjadi pelanggannya. Adapun, secara umum definisi dari perusahaan asuransi sama dengan perusahaan asuransi syariah. Hanya saja perusahaan asuransi syariah menggunakan prinsip-prinsip yang sesuai dengan syariat islam. Berikut jumlah perusahaan asuransi syariah di Indonesia dalam kurun waktu tiga tahun terakhir.

\section{Gambar 1.1 Grafik Jumlah Perusahaan Asuransi Syariah di Indonesia}

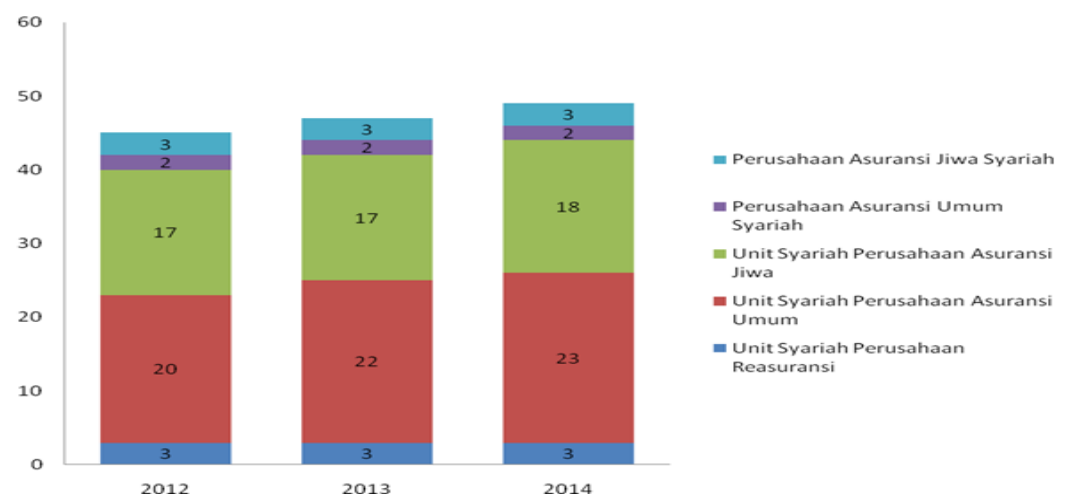

Sumber: Data diolah

Menurut data tersebut, hingga akhir tahun 2014, jumlah perusahaan asuransi syariah di Indonesia mencapai 49 untuk perusahaan asuransi dan reasuransi syariah. Berdasarkan data diatas, terlihat juga bahwa lima diantaranya adalah perusahaan asuransi syariah yang full pledged (tiga perusahaan asuransi jiwa syariah dan dua perusahaan asuransi umum syariah) sedangkan 43 sisanya berbentuk unit syariah (18 unit syariah asuransi jiwa, 23 unit syariah asuransi umum, dan tiga unit syariah reasuransi) (Otoritas Jasa Keuangan, 2014).

Dari banyaknya perusahaan asuransi syariah, Asuransi Jiwa Bersama (AJB) Bumiputera 1912 merupakan salah satu perusahaan asuransi yang sudah memiliki divisi syariah di Indonesia. Didorong oleh semangat nasionalisme untuk meningkatkan kaum pribumi menjadi alasan didirikannya perusahaan Asuransi Jiwa Bersama (AJB) Bumiputera 1912. Salah satu kantor cabang syariah dari Asuransi Jiwa Bersama (AJB) Bumiputera 1912 yang memiliki perkembangan cukup baik adalah Kantor Cabang Syariah (KCS) Palmerah. Dalam perkembangannya, Asuransi Jiwa Bersama (AJB) Bumiputera 1912 Kantor Cabang Syariah Palmerah tidak berbeda jauh dengan perkembangan asuransi syariah secara nasional, dimana pertumbuhan jumlah agen belum bisa diiringi dengan pemegang polis secara konsisten. 
Gambar 1.2 Jumlah Pemegang Polis dan Agen Bersertifikat di AJB Bumiputera 1912 Kantor Cabang Syariah Palmerah

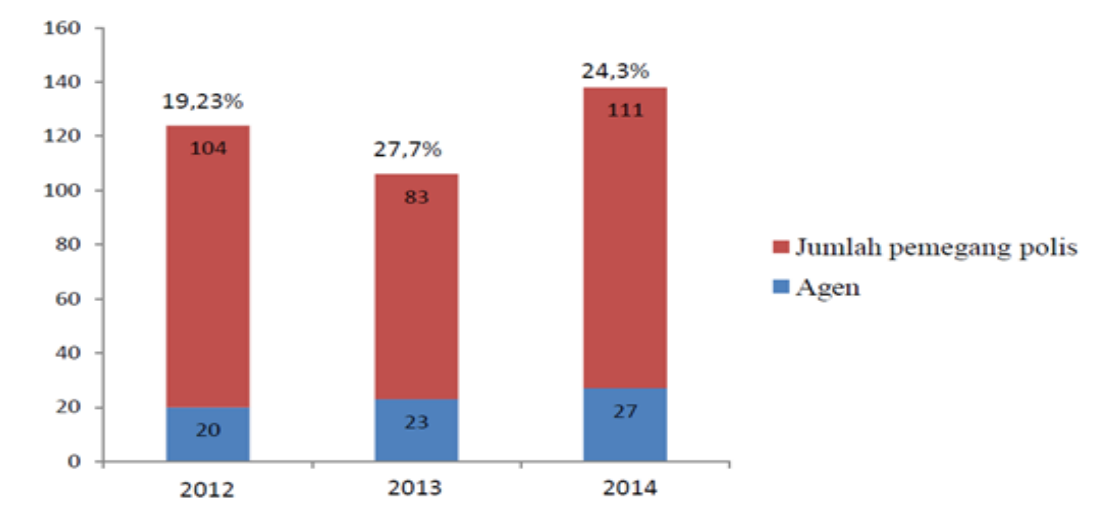

Sumber: AJB Bumiputera 1912 KCS Palmerah, 2014

Berdasarkan grafik di atas, pertumbuhan agen bersertifikat di AJB Bumiputera 1912 Kantor Cabang Syariah Palmerah terus mengalami peningkatan di tahun 2013 dan 2014 dengan masing-masing persentase sebesar 15\% dan 17,4\% dengan jumlah total agen hingga Juni 2014 sebanyak 27 agen. Namun, trend positif tersebut tidak diiringi dengan pertumbuhan jumlah pemegang polis yang bersifat fluktuatif. Dari data tersebut juga dapat disimpulkan, ketika jumlah agen bertambah di tahun 2012 tetapi pemegang polis mengalami grafik penurunan sebesar 25,3\% dan di tahun 2014 perusahaan AJB Bumiputera 1912 kantor cabang syariah Palmerh dapat meningkatkan jumlah pemegang polis dengan presentase sebesar 33,73\% dari tahun sebelumnya.

Untuk melihat produktivitas agen dalam mencari dan mempertahankan pemegang polis maka dapat dipersentasekan antara jumlah agen dengan jumlah pemegang polis disetiap tahunnya, dapat terlihat walaupun di tahun 2013 terjadi kenaikan produktivitas yaitu 27,7\% dibandingkan tahun 2012 yang hanya memiliki tingkat produktivitas $19,23 \%$ tetapi di tahun 2014 produktivitas agen kembali mengalami penurunan 24,3\% atau turun sebesar 3,4\% dibandingkan tahun 2013. Berdasarkan permasalahan tersebut, akan dilakukan penelitian mengenai faktor-faktor dalam kompetensi agen yang mempengaruhi loyalitas nasabah AJB Bumiputera 1912 Kantor Cabang Syariah Palmerah.

\section{TELAAH PUSTAKA}

\section{Asuransi Syariah}

Asuransi diartikan sebagai sikap ta'awun yang telah diatur dengan sistem yang sangat rapi antara sejumlah besar manusia. Semuanya telah siap mengantisipasi suatu peristiwa. Menurut Syakir Sula (2004, hlm. 293), terdapat beberapa indikator yang menjadi perbedaan antara asuransi syariah dengan asuransi konvensional yaitu konsep; adanya unsur gharar, maisir, dan riba; terdapatnya Dewan Pengawas Syariah; akad; Penanganan Risiko, Pengelolaan dana; Investasi; kepemilikan dana; sumber pembayaran klaim; dan keuntugan. 
Berbicara tentang bisnis asuransi, maka tidak bisa dilepaskan dari peran seorang agen. Secara garis besar, definisi agen syariah memiliki kesamaan dengan definisi agen secara umum. Hal ini terlihat dalam DSN-MUI No. 21 Tentang Pedoman Asuransi Syariah menurut pasal 3 ayat (5) tugas dari agen asuransi syariah adalah untuk memberikan jasa keperantaraan untuk memasarkan produk asuransi syariah untuk dan atas nama tertanggung.

\section{Teori Kompetensi}

Watson Wyatt dalam Fuad (2009, hlm. 19) mendefinisikan kompetensi sebagai kombinasi dari pengetahuan (knowledge), keterampilan (skill), dan perilaku (attitude). Keterampilan, pengetahuan, dan perilaku itu dapat diamati dan diterapkan secara kritis untuk susksesnya sebuah organisasi dan prestasi kerja serta kontribusi pribadi karyawan terhadap organisasinya. Dari definisi yang sudah dipaparkan, maka seseorang agen asuransi harus mempunyai kompetensi untuk mengelola pekerjaan dan merencanakan serangkaian aktivitas untuk mencapai target. Karena kompetensi adalah hal dasar yang harus dimiliki seseorang guna mencapai tujuan organisasinya. Selanjutnya, secara garis besar terdapat tiga komponen yang termasuk dalam kompetensi, yaitu:

a) Pengetahuan (Knowledge)

Menurut Rogers, pengetahuan yang dominan tercakup dalam kognitif mempunyai enam tingkatan, yaitu Tahu (Know), Memahami (Comprehension), Aplikasi (Application), Analisis (Analysis), Sintesis (Synthesis), dan Evaluasi (Evaluation)(Sunaryo, 2004, hlm. 25).

b) Keterampilan (Skill)

Pada penelitian yang dilakukan oleh Setiobudi (2007, hlm. 49) menjelaskan bahwa keterampilan terbagi menjadi empat, yaitu Ketrampilan Menjual, Presentation Skill, Kemampuan Bertanya, dan Kemampuan Beradaptasi.

c) Perilaku (Attitude)

Robbins dalam Harrell (2005, hal. 1) perilaku adalah hal terpenting untuk mencapai kesuksesan. Sikap terdiri dari beberapa tingkatan, yaitu Menerima (Receiving), Merespon (Responding), Menghargai (Valuing), dan Bertanggung jawab (Responsible) (dalam Marini, 2009, hal. 11).

\section{Teori Umum Loyalitas Nasabah}

loyalitas secara umum dapat diartikan sebagai kesetiaan seseorang atas suatu produk maupun jasa tertentu. Heskett menandai pelanggan yang loyal dengan ciri-ciri 3 $\mathrm{R}$, yaitu:

1. Retention (hubungan aktif dan berkesinambungan dengan pelanggan yang menghasilkan revenue hasil penjualan produk ataupun jasa);

2. Related Sales of New Products and Service (menjual produk atau jasa baru kepada pelanggan lama); Refferals (pelanggan merekomendasikan kepada calon pelanggan lain yang potensial) (Sofiyan, 2014, hlm. 24).

\section{Hipotesis Penelitian}

Hipotesis sebagai suatu pernyataan tentang dua atau lebih variabel yang saling berhubungan satu dengan yang lainnya sehingga merupakan jawaban sementara dari 
Jurnal Ekonomi dan Perbankan Syariah

Vol. 3. No.1, April 2015: 21-36, ISSN (cet): 2355-1755

pemecahan masalah sebelum diperolehnya data empiris (Sumarsono, 2004, hal. 30).

Peneliti mencoba membuat hipotesis atau dugaan sementara dari penelitian ini, sebagai berikut:

H1 :Kompetensi pengetahuan agen asuransi berpengaruh terhadap loyalitas nasabah.

H2 :Kompetensi keterampilan agen asuransi berpengaruh terhadap loyalitas nasabah.

H3 : Kompetensi perilaku agen asuransi berpengaruh terhadap loyalitas nasabah.

H4 :Kompetensi pengetahuan, keterampilan, dan perilaku secara simultan berpengaruh terhadap loyalitas nasabah.

\section{METODE PENELITIAN}

Metode yang digunakan dalam penelitian ini adalah metode deskriptif melalui pendekatan survey dengan jenis penelitan deskriptif kuantitatif. Populasi yang digunakan pada penelitian ini adalah pemegang polis di perusahaan AJB Bumiputera 1912 Kantor Cabang Syariah Palmerah, dimana pengambilan sample menggunakan metode probabilty sampling dengan cara Simple Random Sampling yaitu teknik yang paling sederhana (simple). Berdasarkan perhitungan dengan rumus slovin, dari total populasi sebanyak 520 nasabah maka diperoleh sampel penelitian sebanyak 226 orang responden yang dibulatkan menjadi 230 responden.

\section{Teknik Analisis Data}

Dalam penelitian ini menggunakan teknik analisis SEM, dengan bantuan SPSS for windows versi 21 dan Lisrel versi 8.8. SEM merupakan generasi kedua teknik analisis multivariate yang memungkinkan peneliti untuk menguji hubungan antara variabel yang kompleks untuk memperoleh gambaran menyeluruh mengenai suatu model. Adapun langkah menggunakan teknis analisis SEM ialah

1. Uji Validitas

2. Uji Reliabilitas

3. Pengujian Asumsi Structural Equation Model.

Setelah melakukan uji vaiditas dan reliabilitas, langkah selanjutnya adalah menguji asumsi-asumsi yang terdapat pada analisis Structural Equation Model. Adapun asumsi-asumsi yang terdapat pada analisis SEM meliputi (Yamin, 2014, hal. 51-56):
a) Multikolinearitas
b) Multivariate Outliers
c) Multivariate Normality
d) Metode estimasi Maximum Likelihood (ML)
e) Metode Estimasi Diagonal Weight Least Square (DWLS)

4. Uji Kecocokan Model.

Setelah menentukan metode estimasi, langkah selanjutnya pada SEM adalah uji kecocokan model. Uji ini digunakan untuk menguji apakah model yang hipotesiskan merupakan model yang baik untuk mempresentasikan hasil penelitian.
a) Goodness offitindex (GFI)
b) Root mean square error of approximation (RMSEA)
c) Chi Square
d) Adjusted Goodness-of-fit-index (AGFI)
e) Comparative fit index (CFI)

5. Evaluasi Kecocokan Model Pengukuran

a) Convergent Validity 


\section{b) Discriminant Validity}

\section{Evaluasi Model Struktural.}

Evaluasi ini adalah mengkonfirmasi hipotesis penelitian yang diajukan peneliti apakah ada hubungan yang signifikan antara variabel laten eksogen dengan variabel laten endogen.

a) Evaluasi secara Parsial.

Evaluasi secara parsial bertujuan untuk melihat secara individual apakah ada pengaruh yang signifikan dari variabel independen terhadap variabel dependen. Pada lisrel, hasil uji parsial dapat dilihat pada output GAMMA.

HO diterima dan Ha ditolak jika nilai t statistic $<1,96$ untuk $\alpha=5 \%$ dimana variabel independen tidak berperngaruh signifikan terhadap variabel dependen. Ha diterima jika nilai t statistik $>1,96$ untuk $\alpha=5 \%$ dimana variabel independen berperngaruh signifikan terhadap variabel dependen.

b) Evaluasi secara Simultan.

Evaluasi ini bertujuan untuk melihat apakah semua variabel independen yang dimasukkan dalam model mempunyai pengaruh secara simultan (bersamasama) terhadap variabel dependen dimana:

H0 diterima dan Ha ditolak jika nilai tstatistik< 1,96 untuk $\alpha=5 \%$ dimana secara simultan variabel independen tidak berperngaruh signifikan terhadap variabel dependen. Ha diterima dan H0 ditolak jika nilai t-statistik-nya $>1,96$ untuk $\alpha=5$ $\%$ dimana secara simultan variabel independen berperngaruh signifikan terhadap variabel dependen.

\section{HASIL DAN ANALISIS}

\section{Karakteristik Responden}

Hasil analisis deskriptif terhadap 230 orang nasabah AJB Bumputera 1912 KCS Palmerah, diketahui perbandingan jumlah nasabah wanita dari pada nasabah laki-laki, yaitu 45:55. Usia yang mendominasi adalah > 40 tahun sebanyak 130 orang atau 56\%, selanjutnya dengan umur 30-39 tahun sebanyak 78 orang atau 34\%, dan terakhir dengan umur lebih dari 20-29 tahun sebanyak 22 orang atau 10\%. Sedangkan berdasarkan pendidikan, nasabah AJB Bumiputera 1912 KCS Palmerah didominasi oleh pendidikan terakhir SMA sebanyak 122 orang atau 53\%, lalu S1 sebanyak 87 orang atau 38\%, dan pendidikan terakhir SMP dan S2 masing-masing sebanyak 10 orang 11 orang atau 4\% dan $5 \%$ saja.

Selain itu dapat terlihat juga sebaran responden berdasarkan pekerjaan, responden yang bekerja sebagai karyawan sebanyak 105 orang atau 46\%, untuk responden yang bekerja sebagai PNS sebanyak 17 orang atau 7\%, dan didominasi oleh nasabah yang bekerja sebagai wiraswasta sebanyak 108 orang atau 47\%. Sedangkan berdasarkan pendapatan menunjukkan bahwa responden dengan pendapatan kurang dari Rp2.000.000 mendominasi sebanyak 93 orang atau 40\%, selanjutnya dengan pendapatan sebesar Rp2.000.000-Rp5.000.000 sebanyak 73 orang atau 32\%, dan terakhir dengan pendapatan lebih dari 5.000.000 sebanyak 64 orang atau $28 \%$.

\section{Hasil Uji Validitas}

Teknik korelasi yang digunakan adalah Korelasi Pearson yang menunjukkan masing-masing nilai korelasi item pertanyaan dengan item total. Maka, dengan menggunakan sampel 230 responden maka derajat kebebasan (degress of freedom) adalah n-2 $=228$. Diketahui pada nilai tabel $r$ dengan derajat bebas (df) $=228$ pada Alpha 0,05 diperoleh 0,1294 yang menjadi batasan (cut off) nilai. Jadi, nilai korelasi harus lebih besar dari 0,1294. Kesimpulan dari seluruh tabel hasil uji valid menunjukkan bahwa pernyataan valid karena nilai Corrected Item Total Correlation ( $\mathrm{r}$ hitung) lebih besar dari nilai $r$ tabel, maka seluruh pernyataan layak digunakan dalam penelitian ini. 
Jurnal Ekonomi dan Perbankan Syariah

Vol. 3. No.1, April 2015: 21-36, ISSN (cet): 2355-1755

\section{Hasil Uji Reliabilitas}

Uji reliabilitas dapat dilihat dari tabel Reliability Statistic yang dihasilkan oleh software SPSS. Reliabilitas suatu variabel dikatakan baik jika memiliki nilai cronbach's alpa $>0,1294$. Berdasarkan hasil pengujian, diperoleh nilai Cronbach's Alpha untuk kompetensi pengetahuan sebesar 0.731, kompetensi perilaku sebesar 0.674, loyalitas nasabah sebesar 0.602 dan untuk kompetensi ketrampilan sebsar 0.710. maka, berdasarkan data tersebut dapat disimpulkan bahwa variabel kompetensi pengetahuan, kompetensi keterampilan, dan kompetensi perilaku dan loyalitas memiliki reliabilitas yang baik karena memilki nilai Cronbach's Alpha yang melebihi r table. Artinya seluruh pertanyaan dari masing-masing variabel memiliki tingkat kehandalan yang baik.

\section{Pengujian Asumsi Pada Structural Equation Model \\ a) Asumsi Multikolinieritas}

Efek multikolinier terhadap model adalah merubah arah tanda koefisien jalur yang dihasilakan sehingga pemeriksaan multikolinier antara variabel sangat dianjurkan. Cara sederhana, mendeteksi multikolinieritas dalam SEM dapat diidentifikasi dengan melihat nilai $\boldsymbol{R}^{\mathbf{2}}$ dari output measurement equation. Jika $\boldsymbol{R}^{\mathbf{2}}$ antara 0,7-1 maka diindikasikan adanya multikolerasi. Pada hasil uji asumsi multikolinearitas, terlihat semua item pernyataan di variabel kompetensi pengetahuan, keterampilan, perilaku, dan loyalitas tidak mengalami gejala multikolinearitas karena nilai $\boldsymbol{R}^{2}$ tidak berada diantara 0,7 - 1 .

\section{b) Asumsi Multivariate Outliers}

Pemeriksaan multivariate outlier dapat dilakukan dengan statistik Mahalanobis Distance $\left(\boldsymbol{d}^{2}\right)>\boldsymbol{X}^{2}(\mathrm{p}<0.001, \mathrm{k})$ dimana $\mathrm{k}$ adalah indikator. Pada asumsi multivariate outlier ini peneliti menggunakan bantuan Microsoft Excel 2007 untuk menentukan nilai chi square dimana dengan rumus $=\operatorname{CHIINV}(0.001,16)$ diperoleh nilai 39,25235.

Berdasarkan hasil pengolahan data, nomor urut responden telah berubah. Posisi baris satu adalah responden nomor delapan diikuti dengan responden nomor 98 dan seterusnya. Dengan memperhatiakan kolom MAH_1 maka nilai Mahalanobis distance responden ke delepan adalah 39,25225 yang berarti lebih kecil dari nilai chi square yaitu 39,25235. Maka dapat disimpulkan tidak terdapat angka yang ekstream atau berbeda jauh dari seluruh pernyataan yang diajukan disetiap variabelnya.

\section{c) Asumsi Multivariate Normality}

Normalitas dalam LISREL dilihat dari normal score-nya. Lisrel 8.8 secara default mengeluarkan dua output uji normalitas yaitu uji normalitas secara univariate dan multivariate. Berdasarkan hasil output di atas dapat diketahui bahwa pemeriksaan normalitas variabel data secara multivariate terlihat bahwa data tidak berdistribusi normal multivariate karena p-value di bawah 0,05.

Kesimpulan dari uji asumsi yang telah dilakukan, terdapat satu asumsi yang tidak terpenuhi yaitu uji asumsi multivariate normality. Hal ini akan menentukan metode estimasi yang digunakan pada pengujian selanjutnya karena keadaan data berdistribusi tidak normal memiliki pendekatan yang berbeda. Berdasarkan hal tersebut, maka penulis melakukan pengolahan data dengan metode DWLS (Diagonal Weight Least Square) untuk pengujian selanjutnya. 


\section{Uji Kecocokan Model}

Tabel 4.1Hasil Uji Kecocokan Model

\begin{tabular}{|l|l|l|l|}
\hline Jenis Uji kecocokan Model & Kriteria & Output & Ket \\
\hline GFI & Mendekati 1 & 0,942 & Good fit \\
\hline RMSEA & $<0,08$ & 0,08 & Adequate fit \\
\hline Chi Square & $\mathrm{P} \geq 0,05$ & 0,000 & Poor fit \\
\hline AGFI & $\geq 0,09$ & 0,920 & Good fit \\
\hline CFI & $\geq 0,09$ & 0,954 & Good fit \\
\hline
\end{tabular}

Sumber: Data dioleh

Berdasarkan keseluruhan pengukuran goodness-of-fit tersebut di atas mengindikasikan bahwa model yang diajukan dalam penelitian dapat diterima (secara keseluruhan dinyatakan fit). Dengan kondisi data moderate non normal, penaksir DWLS menghasilkan standard error lebih kecil untuk setiap koefisien regresi persamaan pengukuran dan struktural dibandingkan dengan metode RML

\section{Evaluasi Kecocokan Pengukuran}

Salah satu tujuan utaman SEM adalah menguji tingkat validitas variabel laten dari teori model pengukuran yang diajukan. Ada dua pemeriksaan validitas laten, yaitu convergent validity dan discriminate validity.

\section{a) Convergent Validity}

Dalam analisis SEM, model pengukuran biasa disebut confirmatory factor analysis model (model CFA). Model CFA digunakan untuk mengukur tingkat validitas konvergen yang dilihat dari nilai faktor loading indikator terhadap variabel konstruknya. Indikator dinyatakan memiliki nilai validitas yang baik bila memiliki nilai faktor loading $\geq 0,5$. Berikut model CFA yang dikembangkan dalam penelitian ini:

\section{Gambar 4.3 Confirmatory Factor Analysis Model}

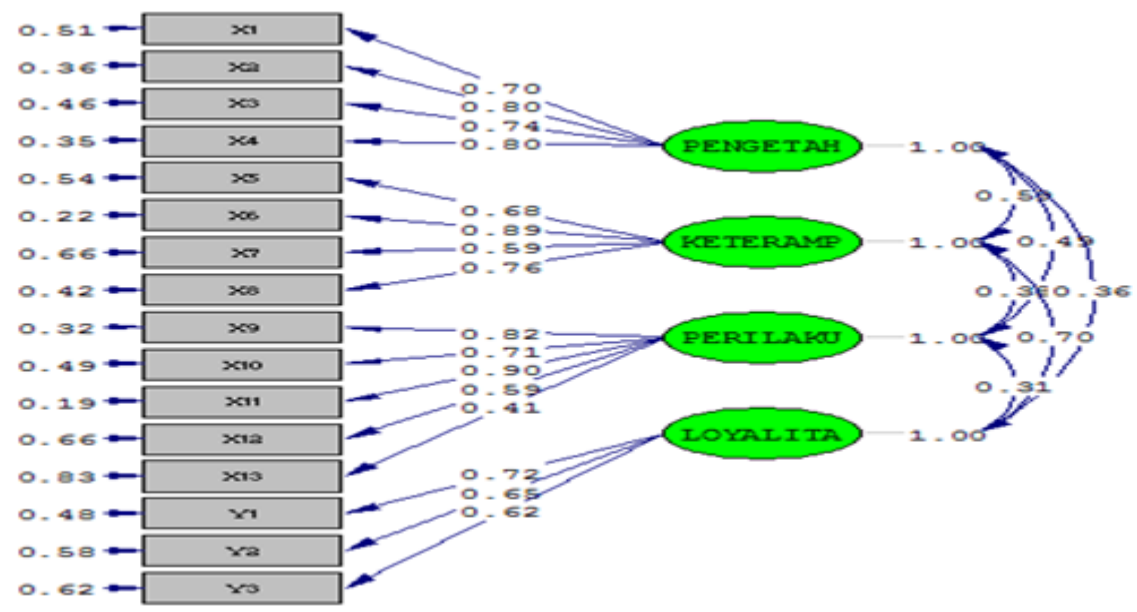

Sumber: Data diolah 
Jurnal Ekonomi dan Perbankan Syariah

Vol. 3. No.1, April 2015: 21-36, ISSN (cet): 2355-1755

Pada model CFA diatas terlihat X13 memiliki faktor loading 0,41 yang berarti $\leq 0,5$ sehinga dinyatakan sebagai indikator yang memiliki convergent validity yang tidak baik sehingga akan dihilangkan dari model. Maka, model yang diajukan pada pengujian selanjutnya adalah

\section{Gambar 4.4 Model Penelitian Setelah Perbaikan}

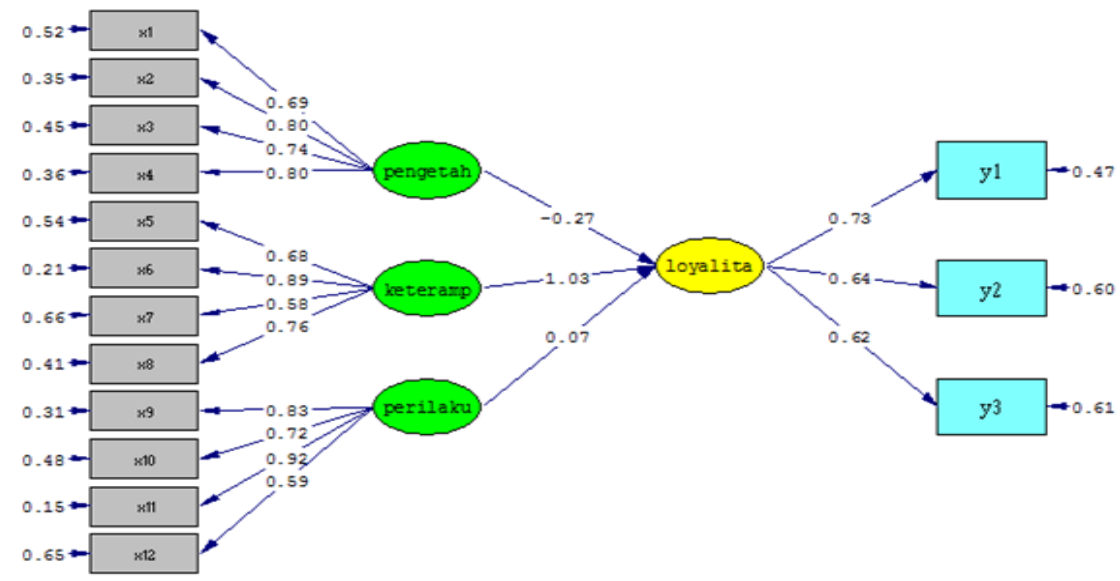

Chi-Square $=242.78, d f=99, \mathrm{P}-\mathrm{value}=0.00000, \mathrm{RMSEA}=0.080$

Sumber: Data diolah

\section{b) Discriminant validity}

Discriminant validity merujuk kepada sejauh mana variabel konstrak berbeda dengan variabel konstrak lainnya. Evaluasi discriminant validity adalah membandingkan nilai akar average variance extracted (AVE) dari konstrak dengan korelasi antar konstrak. Berdasarkan hasil perhitungan AVE, didapatkan nilai AVE pengetahuan sebesar 0.58, AVE ketrampilan 0.55, AVE perilaku sebesar 0.50 dan AVE loyalitas Sebesar 0.52. Dari perhitungan diatas menunjukkan bahwa nilai AVE berada diatas 0.5 yang artinya nilai AVE dapat diterima sehingga dapat dilanjutkan pada perhitungan selanjutnya, yaitu melihat korelasi antar variabel laten yang dapat dilihat pada PHI dari output lisrel 8.8, berikut korelasi antar variabel konstrak:

\section{Tabel 4.2Korelasi Antar Variabel}

\begin{tabular}{|c|c|c|c|c|}
\hline \multicolumn{5}{|l|}{ PHI } \\
\hline PENGETAH & KETERAMP & PERILAKU & LOYALITA & \\
\hline -------- & -------- & -------- & -------- & \\
\hline PENGET AH & 1.00 & & & \\
\hline KETERAMP & 0.59 & 1.00 & & \\
\hline PERIL AूKU & 0.49 & 0.38 & 1.00 & \\
\hline LOYALL ITẢ & 0.36 & 0.70 & 0.31 & 1.00 \\
\hline
\end{tabular}

Sumber: Data diolah 
30 | Fariska \& Syahbudin: Pengaruh Kompetensi Agen Asuransi Syariah Terhadap Loyalitas Nasabah.......

Setelah diketahui korelasi antar variabel, langkah selanjutnya kemudian dihitung nilai akar AVE setiap variabel laten serta menggabungkan dengan nilai korelasi seperti dalam tabel berikut:

Tabel 4.3 Akar AVE dan Korelasi

\begin{tabular}{|l|l|l|l|l|}
\hline & Pengetahuan & Keterampilan & Perilaku & Loyalitas \\
\hline Pengetahuan & 0.76 & & & \\
\hline Keterampilan & 0.59 & 0.74 & & \\
\hline Perilaku & 0.49 & 0.38 & 0.77 & \\
\hline Loyalitas & 0.36 & 0.70 & 0.31 & 0.72 \\
\hline
\end{tabular}

Sumber: Data diolah

Korelasi antara pengetahuan dengan keterampilan adalah 0.59, pengetahuan dengan perilaku adalah 0.49 , pengetahuan dengan loyalitas adalah 0.36 , sedangkan akar AVE pengetahuan adalah 0.76 sehingga akar AVE pengetahuan lebih besar korelasinya dengan variabel laten lainnya. Demikian juga dengan akar AVE keterampilan, akar AVE perilaku, dan akar AVE loyalitas lebih besar dari korelasi dengan variabel lainnya. Hal ini menunjukkan sifat discriminant validity yang baik. Maka dapat disimpulkan, model yang diajukan setelah menghilangkan indikator X13 memiliki kecocokan model pengukuran sehingga dapat dilanjutkan pada evaluasi model struktural.

\section{c) Evaluasi Model Struktural}

Tahap akhir dalam analisis SEM adalah evaluasi model struktural. Evaluasi ini digunakan untuk mengkonfirmasi hipotesis penelitian yang diajukan apakah ada hubungan yang signifikan antara variabel laten eksogen dengan variabel laten endogen.

\section{Evaluasi secara Parsial}

Evaluasi hipotesis secara parsial dapat dilihat dari path diagram t statistik pada dibawah ini:

\section{Gambar 4.5 Nilai t Statistik Model Struktura}

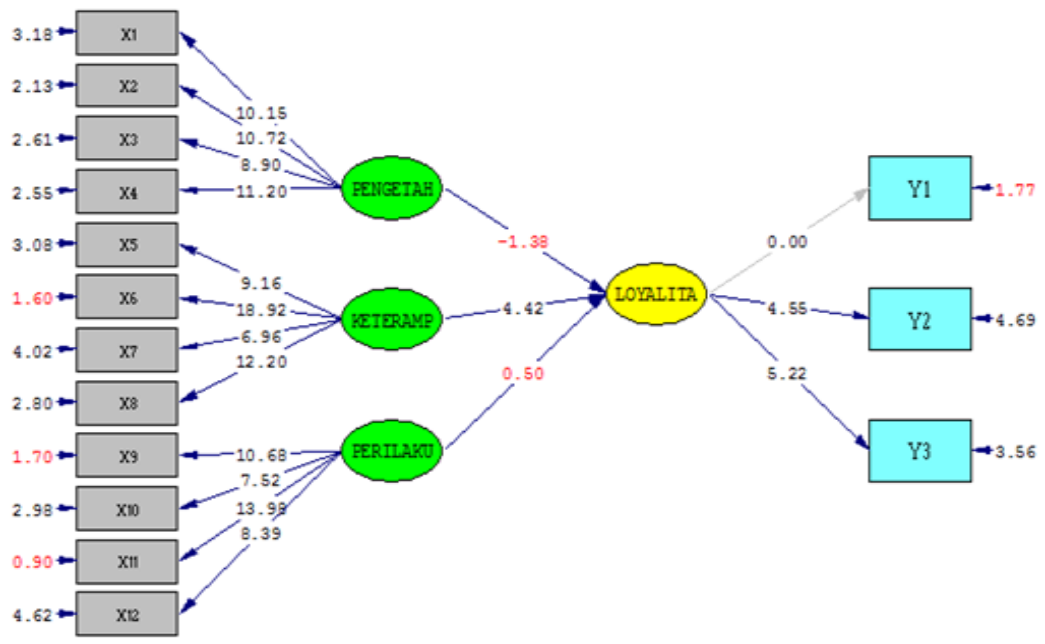

Sumber: Data diolah 
Jurnal Ekonomi dan Perbankan Syariah

Vol. 3. No.1, April 2015: 21-36, ISSN (cet): 2355-1755

Hipotesis 1

\section{H1: Kompetensi pengetahuan agen asuransi berpengaruh terhadap loyalitas nasabah.}

Berdasarkan hasil perhitunganpada gambar t statistik dimana nilai kompetensi pengetahuan pada loyalitas nasabah sebesar -1,38 tidak signifikan pada $t$ hitung $<1,96$, maka dapat disimpulkan bahwahipotesis 1 tidak didukung. Artinya, secara statistik dapat ditunjukkan kompetensi pengetahuan agen asuransi tidak mempunyai pengaruh langsung dan negatif terhadap loyalitas nasabah. Hal ini mengindikasikan bahwa meningkatnya kompetensi pengetahuan belum tentu mengakibatkan meningkatnya loyalitas nasabah karena melihat hasil yang negatif namun tidak signifikan.

Hasil penelitian ini tidak mendukung teori dari Plato yang mengatakan bahwa pengetahuan menjadi hal dasar yang harus dimiliki oleh seorang karyawan dalam menjalankan tugasnya untuk mencapai tujuan organisasi. Maka dapat dikatakan teori tentang pengetahuan tidak berlaku pada nasabah AJB Bumiputera 1912 Kantor Cabang Syariah Palmerah, tetapi di derah lain teori di atas bisa berlaku pada perusahaan asuransi lain sehingga kondisi tersebut bersifat kasuistik (berhubungan dengan kasus tertentu). Hal ini disebabkan karena nasabah AJB Bumiputera 1912 KCS Palmerah lebih mengutamakan faktor lain untuk meningatkan loyalitasnya.

\section{Hipotesis 2}

\section{H2: Kompetensi keterampilan agen asuransi berpengaruh terhadap loyalitas nasabah.}

Berdasarkan hasil perhitungan pada gambar t statistik dimana nilai kompetensi keterampilan pada loyalitas nasabah sebesar 4,42 signifikan pada $t$ hitung $>1,96$, maka dapat disimpulkan bahwa hipotesis 2 didukung. Artinya,secara statistik dapat ditunjukkan bahwa kompetensi keterampilan mempunyai pengaruh langsung dan positif (meningkatkan) terhadap loyalitas nasabah. Hal inimengindikasikan bahwa peningkatan kompetensi keterampilan pasti dapat meningkatkan Loyalitas nasabah.

Hasil penelitian ini mendukung dengan penelitian yang dilakukan oleh Ari (2005) bahwa keahlian tenaga penjual asurans dalam memasarkan produk asuransi berengaruh secara positif dan signifikan terhadap loyalitas nasabah. Jadi kompetsni keterampilandapat meningkatkan loyalitas nasabah Asuransi AJB Bumiputera 1912 Kantor Cabang Syariah Palmerah. Hal ini mengindikasikan bahwa meningkatkan kompetensi keterampilan mengakibatkan naiknya loyalitas nasabah. Dalam upaya meningkatkan loyalitas nasabah, AJB Bumiputera 1912 Kantor Cabang Syariah Palmerah senantiasa meningkatkan keterampilan para agennya dengan cara mengadakan evaluasi disetiap pekannya untuk menjaga produktivitas keahlian agen. Selain itu, upaya lainnya adalah mendatangkan mentor agen dari kantor pusat untuk melatih agen dalam mempertahankan dan mendapatkan nasabah. 


\section{Hipotesis 3}

H3: Kompetensi perilaku agen asuransi berpengaruh terhadap loyalitas nasabah.

Berdasarkan hasil perhitungan pada gambar t statistik dimana nilai kompetensi keterampilan pada loyalitas nasabah sebesar 0.50 tidak signifikan pada $t$ hitung $<1,96$, maka hipotesis 3 tidak didukung karena walaupun pengaruh positif namun tidak signifikan dari kompetensi perilaku terhadap loyalitas nasabah. Hal ini mengindikasikan bahwa meningkatnya kompetensi perilaku belum tentu mengakibatkan meningkatnya loyalitas nasabah karena melihat hasil yang positif namun tidak signifikan.

Hasil penelitian ini tidak mendukung teori yang di sampaikan oleh Robins (2005) yang menyatakan bahwa perilaku merupakan hal terpenting dalam mencapai kesuksesan penjualan. Maka dapat dikatakan teori tentang kompetensi perilaku tidak berlaku pada nasabah AJB Bumiputera 1912 Kantor Cabang Syariah Palmerah, tetapi di derah lain teori di atas bisa berlaku pada perusahaan asuransi lain sehingga kondisi tersebut bersifat kasuistik (berhubungan dengan kasus tertentu). Hal ini disebabkan karena nasabah AJB Bumiputera 1912 KCS Palmerah lebih mengutamakan faktor lain untuk meningatkan loyalitasnya.

\section{d) Evaluasi secara Simultan}

Pengujian hipotesis secara simultan/serempak dapat dilihat dari output lisrel 8.8 pada structural equation sebagai berikut:

\section{Tabel 4.4 model struktura simultan}

$$
\begin{aligned}
& \text { Structural Equation } \\
& \text { loyalita }=-0.26^{\star} \text { pengetah }+1.04^{*} \text { keteramp }+0.068^{*} \text { perilaku, Errorvar } .=0.16 \\
& R^{2}=0.84 \\
& (0.19) \quad(0.23) \quad(0.13) \quad(0.27) \\
& \begin{array}{llll}
-1.38 & 4.42 & 0.50 & 2,25
\end{array}
\end{aligned}
$$

Sumber: Data diolah

\section{Hipotesis 4}

H4: Kompetensi pengetahuan, keterampilan, dan perilaku secara simultan berpengaruh terhadap loyalitas nasabah.

Berdasarkan hasil perhitungan pada table persamaan struktural dimana nilai $\mathrm{t}$ hitung gabungan dari kompetensi pengetahuan, keterampilan, dan prilakupada loyalitas nasabah sebesar 2,25 signifikan pada $t$ hitung > 1,96, maka dapat disimpulkan bahwa hipotesis 4 didukung. Artinya,secara statistik dapat ditunjukkan bahwa kompetensi pengetahuan, keterampilan, dan perilaku mempunyai pengaruhlangsung positif terhadap 
Jurnal Ekonomi dan Perbankan Syariah

Vol. 3. No.1, April 2015: 21-36, ISSN (cet): 2355-1755

loyalitas nasabah. Hal inimengindikasikan bahwa peningkatan kompetensi pengetahuan, keterampilan, dan perilaku secara bersamaan pasti dapat meningkatkan Loyalitas nasabah.

Hasil evaluasi secara simultan juga menunjukkan besaran kontribusi yang dihasilkan dari ketiga variabel kompetensi terhadap loyalitas nasabah yaitu sebesar 0.85 . Artinya, jika kompetensi pengetahuan, keterampilan, dan perilaku dijalankan secara bersamaan maka akan mempunyai pengaruh terhadap loyalitas nasabah sebesar $85 \%$ dan $15 \%$ lainnya dipengaruhi oleh variabel yang tidak diteliti dalam penelitian ini. Bila melihat besarnya pengaruh ketiga variabel secara simultan, maka hasil penelitian ini mendukung dengan penelitian yangdilakukan oleh Sofiyan (2014) yang berjudul faktorfaktor yang mempengaruhi loyalitas nasabah asuransi, hasil penelitian menyatakan bahwa kompetensi agen asuransi adalah faktor paling berpengaruh terhadap peningkatan loyalitas nasabah.

\section{SIMPULAN}

Hasil akhir analisis SEM menunjukkan kompetensi pengetahuan terhadap loyalitas tidak ada pengaruh secara signifikan dan korelasi keduanya bersifat negative (berlawanan). Pada kompetensi Keterampilan memiliki pengaruh signifikan secara positif antara keterampilan terhadap loyalitas. Sedangkan pada variabel perilaku terhadap loyalitas tidak memiliki pengaruh signifikan perilaku terhadap loyalitas walaupun korelasinya bersifat positif.

Sedangkan secara simultan, kompetensi pengetahuan, keterampilan, dan perilaku terhadap loyalitas nasabah secara bersamaan memiliki pengaruh yang signifikan dan posotif terhadap loyalitas nasabah. Adapun variabel yang memiliki pengaruh signifikan terbesar terhadap loyalitas nasabah AJB Bumiputera 1912 Kantor Cabang Syariah Palmerah adalah variabel kompetensi keterampilan dengan nilai t hitung sebesar 4,42.

Berdasarkan hasil penelitian yang dilakukan, maka saran yang dapat dikemukakan dalam penelitian ini adalah: Bagi manajemen perusahaan Asuransi Jiwa Bersama Bumiputera 1912 Kantor Cabang Syariah Palmerah disarankan agar tetap mempertahankan kompetensi pengetahuan, kompetensi keterampilan, dan kompetensi perilaku para agen karena hal tersebut dapat meningkatkan loyalitas nasabah secara signifikan. Untuk peneliti selanjutnya sebaiknya peneliti menambahkan jumlah sampel penelitian dan menambah elemen variabel penelitian ataupun dengan menambahkan perusahaan yang diteliti agar data yang dihasilkan lebih akurat dan dapat diketahui faktor-faktor lain yang dapat mempengaruhi loyalitas nasabah atau pun dapat membandingkan di antara keduanya.

\section{DAFTAR PUSTAKA}

AJB Bumiputera 1912. (2011). Materi Pendidikan dan Pelatihan Agen Tingkat Lanjut 1. Jakarta: Direktorat Pemasaran AJB Bumiputera.

Amrin, Abdullah. (2006a). Asuransi Syariah: Keberadaaan dDan Kelebihannya dDi Tengah Asuransi Konvensional. Jakarta: PT. Elex Media Komputindo. 
34 | Fariska \& Syahbudin: Pengaruh Kompetensi Agen Asuransi Syariah Terhadap Loyalitas Nasabah.......

Amrin, Abdullah. (2007b). Strategi Pemasaran Asuransi Syariah. Jakarta: PT. Gramedia Pustaka Utama.

Amrin, Abdullah. (2011c). Meraih Berkah Melalui Asuransi Syariah. Jakarta: PT. Elex Media Komputindo.

Anwar, Khoiril. (2007). Asuransi Syariah, Halal dan Maslahat. Solo: Tiga Serangkai.

Arikunto, S. (2006). Prosedur Penelitian: Suatu Pendekatan Praktek. Jakarta: Rineka Cipta.

Bua, Hasanudin. (2009). Pengaruh Kompetensi Agen Terhadap Kepercayaan Konsumen: Pada Perusahaan Asuransi Gabungan Tabungan dan Risiko di Sulawesi Tenggara. Jurnal Ekonomi Vol. XIX. No 1, 57.

Cicilia, Sanny. (2013, 13 Desember). Agen Asuransi Jiwa Syariah Wajib Sertifikasi. Diperoleh 26 November 2014, dari http://keuangan.kontan.co.id/news/agenasuransi-jiwa-syariah-wajib-sertifikasi.html

Erlina. (2011). Metode Penelitian. Medan: USU Pres

Fuad, N. \& Ahmad, G. (2009). Integrated Human Resources Development. Jakarta: PT. Grasindo.

Harell, Keith. (2005). Attitude Is Everything (2nd). Jakarta: PT. Gramedia Pustaka Utama.

Hermansah. (2014, Oktober 16). Pasar Asuransi Terbuka Lebar. Koran Sindo. Jakarta:Koran Sindo, Koran Sindo 19.

Indriantoro, N. \& Bambang, S. (2002). Metedologi Penelitian Bisnis Untuk Akuntansi dan Manajemen. Yogyakarta: BPFE.

Iqbal, Muhaimin. (2005). Asuransi Umum Syariah Dalam Praktik. Jakarta: Gema Insani.

Karsono. (2008). Peran Mediasi Kepuasan Pelanggan, Citra Perusahaan, dDan Biaya Switching dDalam Pengaruh Kualitas Pelayanan Kesetiaan Pelanggan. Jurnal Manajemen dan Kewirausahaan Vol 6 No 2, 12.

Karyanto, D. \& Koen, Y. (2010). Cara Cepat Jadi Agen Asuransi. Jakarta: PT. Gramedia Pustaka Utama.

Keraf, A.S. \& Dua, M. (2001). Ilmu Pengetahuan Sebagai Tinjauan Filosofis. Yogyakarta: Kanisius.

Kotler, Philip. (2002). Manajemen Pemasaran: Analisis, Perencanaan, Implementasi, dan Kontrol. Jakarta: Prenhalindo.

Kuncoro, Mudrajad. (2003). Metode Riset Untuk Bisnis dan Ekonomi: Bagaimana Meneliti dan Menulis Tesis?.. Jakarta: Erlangga.

Kuncoro, O.S. (2013). Pengaruh Etika Confucius tTerhadap Kewirausahaan, Kemampuan Usaha, dan Kinerja Usaha Pedagang Eceran Etnis Thionghoa di Surabaya. Disertasi. Surabaya: Universitas 17 Agustus 1945.

Kurniawan, Fajar. (2014, 20 Oktober). Agen Asuransi, Ujung Tombak Edukasi Masyarakat. Diperoleh 7 Desember 2014, dari http://wartaekonomi.co.i/agenasuransi-ujung-tombak-edukasi-masyarakat.html

Madya, F.I. (2008). Peranan Agen Dalam Pengembangan Bisnis Asuransi Syariah. Skripsi. Jakarta: Universitas Islam Negeri Syarif Hidayatullah.

Manurung, A.H. \& Rizky, L.T. (2009). Succesfull Financial Planner: A Complete Guide. Jakarta: Grasindo

Marini, Dina. (2009). Gambaran Pengetahuan, Sikap, Dan Tindakan. Skripsi:. Universitas Sumatera Utara (USU).

MES. (2014). Sharia Economic Outlook 2014. Jakarta: Masyakat Ekonomi Syariah.

Mosahab, Rahim. (2010). Service Quality, Customer Satisfaction And Loyality: A Test Of Mediation. Intenational Business Reasearch Vol. 3 No 4, 73.

Noviyarni. (2011). Peranan Agen Dalam Meningkatkan Nasabah Asuransi Syariah: Pada AJB Bumiputera Syariah Cabang Ciputat. Skripsi. Jakarta: Universitas Islam Negeri Syarif Hidayatullah. 
Jurnal Ekonomi dan Perbankan Syariah

Vol. 3. No.1, April 2015: 21-36, ISSN (cet): 2355-1755

Oswari, T. \& Suhendra, E.S. (2013). Proyeksi Manajemen Risiko Operasional Pembukaan Kantor Cabang Asuransi Di Indonesia. Jurnal Asuransi dan Manajemen Resiko Vol 1 No 2, 38.

Prameswari, N.P. (2010). Analisis Faktor-faktor yang mempengaruhi Loyalitas Konsumen pada Asuransi Prudential di Kota Semarang. Skripsi. Semarang: Universitas Diponogoro.

Prihantono, M.W. (2001). Manajemen Pemasaran dan Tata Usaha Asuransi. Yogyakarta: Kanisius.

Qureshi, A.A. (2011). Analyzing Sharia'h Compliant Issues Currently Faced By Islamic Insurance. Interdisciplinary Journal of Contemporary Reasearch In Business Vol. 3 No 5, 279.

Riduwan. (2004). Metode dan Teknis Menyusun Tesis. Jakarta: Alfabet.

Santoso, Singgih (2009). Panduan Lengkap Menguasai Statistik Dengan SPSS 17. Jakarta: PT. Gramedia Komputindo.

Sauri, Sofian. (2014, November 10). Personal Interview.

Sekaran, Uma. (2006). Metedologi Penelitian Untuk Bisnis. Jakarta: Salemba Empat.

Sendra, Ketut. (2002). Panduan Sukses Menjual Asuransi. Jakarta: PPM

Setiobudi, B.D. (2007). Analisis Faktor-Faktor yang Memepengaruhi Selling SkillTterhadap Kinerja Penjualan. Tesis. Semarang: Universitas Diponogoro.

Setyanto, A.D. (2010). Pengaruh Kualitas Pelayanan Terhadap Loyalitas Nasabah dan Komplain: Pada Asuransi Jiwa Di AJB Bumiputera 1912 Kantor Cabang Magelang. Skripsi. Surakarta: Universitas Sebelas Maret.

Siregar, S. (2014). Metode Penelitian Kuantitatif. Jakarta: Kencana Prenadamesia Group.

Sofiyan, Wahyudi. (2014). Faktor-Faktor yYang Mempengaruhi Loyalitas Nasabah:Ppada AJB Bumiputera 1912 Divisi Syariah. Skripsi. Jakarta: Universitas Islam Negeri Syarif Hidayatullah.

Sudarsono, Heri. (2003). Bank dan Lembaga Keuangan Syari'ah. Yogyakarta: CV. Adipura Djogja.

Sudjana. (2000). Metode Statistik. Bandung: Tarsito.

Sugiyono. (2006a). Statistika Untuk Penelitian. Bandung: Alfabet.

Sugiyono. (2009b). Metode Penelitian Kuantitatif dan Kualitatif. Bandung: Alfabeta.

Sugiyono. (2012c). Metode Penelitian Kuantitatif, Kualitatif, dan $R$ \& D. Bandung: Alfabeta.

Sula, M.S. (2004). Asuransi Syariah (Life And General): Konsep dan Sistem. Jakarta: Gema Insani.

Sumarsono, H.M.S. (2004). Metode Riset Sumber Daya Manusia. Yogyakarta: Graha Ilmu.

Sunaryo. (2004). Psikologi untuk Keperawatan. Jakarta: Buku Kedokteran.

Susetyaningsih, Ari. (2006). Analisis Faktor Keahlian dDan Kepercayaan pPada Tenaga Penjualan tTerhadap Kepuasan Nasabah Guna Mencapai Loyalitas: pPada Asuransi Jasindo Cabang Semarang. Tesis. Semarang: Universitas.

t.n, (2012-2014). Statistik Asuransi Syariah. Diakses melalui www.ojk.go.id tanggal 10 Maret 2015.

Tan, Inggrid. (2009). Buku Pintar Asuransi. Jakarta: CV. Andi.

Thoha, H. \& Hutapea, P. (2008). Kompetensi Plus: Teori, Desain, Kasus, dan Penerapan Untuk HRD Organisasi Yang Dinamis. Jakarta: PT. Gramedia Pustaka Utama.

Tunggal, A.D. (1998). Peraturan Perundang-Undangan Perusahaan Asuransi di Indonesia 1992-1997. Jakarta: Harvarindo.

Umar, Husein. (2003). Metode Penelitian Bisnis: Panduan Mahasiswa Untuk Melaksanakan Riset. Jakarta: PT. Gramedia Pustaka Utama.

Utami, C.W. (2006). Manajemen Ritel Strategi dan Implementasi Ritel Modern. Jakarta: Salemba Empat. 
36 | Fariska \& Syahbudin: Pengaruh Kompetensi Agen Asuransi Syariah Terhadap Loyalitas Nasabah.......

Vaqih, Iswandi. (2014). Pengaruh Brand Characteristic tTerhadap Kepuasan Nasabah. Skripsi. Yogyakarta: Universitas Islam Negeri Sunan Kalijaga.

Widodo, Sugeng. (2011). Mindset Sukses Agen Asuransi. Jakarta: PT. Gramedia. Yamin, Sofyan. (2014). Rahasia Olah Data Lisrel. Jakarta: Mitra Wacana Media 